\title{
A rapid immunization strategy with a live-attenuated tetravalent dengue vaccine elicits protective neutralizing antibody responses in non-human primates
}

\section{Yuping Ambuel ${ }^{1}$, Ginger Young ${ }^{1}$, Joseph N. Brewoo ${ }^{1}$, Joanna Paykel ${ }^{1}$, Kim L. Weisgrau ${ }^{2}$, Eva G. Rakasz ${ }^{2}$, Aurelia A. Haller ${ }^{3}$, Michael Royals ${ }^{4}$, Claire Y.-H. Huang ${ }^{5}$, Saverio Capuano ${ }^{2}$, Dan T. Stinchcomb ${ }^{3}$, Charalambos D. Partidos ${ }^{1 *}$ and Jorge E. Osorio ${ }^{1}$}

1 Takeda Vaccines, Inc., Madison, WI, USA

${ }^{2}$ Wisconsin National Primate Research Center, University of Wisconsin-Madison, Madison, WI, USA

${ }^{3}$ Takeda Vaccines, Inc., Ft Collins, CO, USA

${ }^{4}$ PharmaJet Inc., Golden, CO, USA

${ }^{5}$ Division of Vector-Borne Diseases, Centers for Disease Control and Prevention, Ft. Collins, CO, USA

\section{Edited by:}

Simona Zompi, University of

California Berkeley, USA

\section{Reviewed by:}

Hari Mohan Saxena, Guru Angad Dev Veterinary and Animal Sciences

University, India

Diego A. Vargas-Inchaustegui,

National Cancer Institute, USA

\section{*Correspondence:}

Charalambos D. Partidos, Takeda Vaccines, Inc., 504 S. Rosa Road, Suite 200, Madison, WI 53719, USA e-mail: harry.partidos@takeda.com
Dengue viruses (DENVs) cause approximately 390 million cases of DENV infections annually and over 3 billion people worldwide are at risk of infection. No dengue vaccine is currently available nor is there an antiviral therapy for DENV infections. We have developed a tetravalent live-attenuated DENV vaccine tetravalent dengue vaccine (TDV) that consists of a molecularly characterized attenuated DENV-2 strain (TDV-2) and three chimeric viruses containing the pre-membrane and envelope genes of DENV-1, -3 , and -4 expressed in the context of the TDV-2 genome. To impact dengue vaccine delivery in endemic areas and immunize travelers, a simple and rapid immunization strategy (RIS) is preferred. We investigated RIS consisting of two full vaccine doses being administered subcutaneously or intradermally on the initial vaccination visit (day 0 ) at two different anatomical locations with a needle-free disposable syringe jet injection delivery devices (PharmaJet) in non-human primates. This vaccination strategy resulted in efficient priming and induction of neutralizing antibody responses to all four DENV serotypes comparable to those elicited by the traditional prime and boost ( 2 months later) vaccination schedule. In addition, the vaccine induced $\mathrm{CD}^{+}$and $\mathrm{CD} 8^{+} \mathrm{T}$ cells producing IFN- $\gamma$, IL-2, and TNF- $\alpha$, and targeting the DENV-2 NS1, NS3, and NS5 proteins. Moreover, vaccine-specific T cells were cross-reactive with the non-structural NS3 and NS5 proteins of DENV-4. When animals were challenged with DENV-2 they were protected with no detectable viremia, and exhibited sterilizing immunity (no increase of neutralizing titers post-challenge). RIS could decrease vaccination visits and provide quick immune response to all four DENV serotypes. This strategy could increase vaccination compliance and would be especially advantageous for travelers into endemic areas.

Keywords: dengue, vaccine, non-human primates, neutralizing antibodies, needle-free delivery, $T$ cell responses

\section{INTRODUCTION}

Millions of people living in tropical and subtropical parts of the world are infected with dengue viruses (DENVs) each year $(1,2)$. The dramatic spread of the disease has been mainly attributed to the geographical expansion of the mosquito vector combined with inadequate measures of vector control, increased human travel, and urbanization (3). DENVs circulate in nature as four distinct serotypes (DENV-1 to DENV-4), each capable of causing a spectrum of disease ranging from subclinical infection to dengue fever (DF), and sometimes to life-threatening dengue hemorrhagic fever (DHF), and dengue shock syndrome (DSS) $(1,4,5)$. Normally, infection with one dengue serotype will confer long-term protection against reinfection by the same serotype. However, in case of reinfection by a heterologous dengue serotype, there is the potential risk of antibody-dependent enhancement (ADE) of disease associated with the presence of cross-reactive antibodies (6) and/or cross-reactive T cells $(7,8)$. Therefore, vaccine development against DENV has focused on tetravalent formulations that can simultaneously provide protection to all four DENV serotypes.

Currently, there are several candidate DENV vaccines at various stages of preclinical and clinical testing (9). This article describes a live-attenuated tetravalent dengue vaccine (TDV) consisting of a molecularly characterized attenuated DENV-2 strain (TDV-2) and three chimeric viruses containing the pre-membrane and envelope genes of DENV-1, -3 , and -4 expressed in the context of the TDV-2 genome (TDV-1, TDV-3, and TDV-4, respectively) (1015). TDV has been extensively tested in preclinical studies (16, 17), two completed Phase 1 clinical trials, and is currently tested in Phase 2 clinical trials in dengue endemic areas. It was shown to be well-tolerated in healthy adults and induced neutralizing 
antibody responses to all four dengue serotypes (Osorio et al., in preparation; George et al., in preparation).

To improve dengue vaccine delivery globally and in diverse clinical settings an easy delivery method is required combined with a vaccination schedule that will improve compliance. Delivery approaches such as those using jet injectors have been considered as alternatives to the conventional needle and syringe (N-S) injection, with some on the market, and others being tested in clinical trials (18). In this non-human primates (NHP) study, we evaluated the administration of TDV via the subcutaneous (SC) or intradermal (ID) routes using a needle-free delivery device developed by PharmaJet $(\mathrm{PhJ})$. In addition, we investigated rapid immunization strategy (RIS) to administer animals with double doses of vaccine (two separate injection sites, one dose at each site) on day $0(0$, 0 ). Our results indicated that this RIS strategy induced immune responses comparable to those elicited when two doses are given 53 days apart.

\section{MATERIALS AND METHODS VIRUSES AND VACCINES}

DENV-2 New Guinea C (NGC) used as challenge virus in this study was generously provided by Dr. Steven Whitehead (National Institutes of Health, Bethesda, MD, USA). For neutralizing antibody assays, we used virus strains from which the prM and $\mathrm{E}$ genes of each live-attenuated dengue vaccine serotype were derived (DENV-1 16007, DENV-2 16681, DENV-3 16562, and DENV-4 1036). DENVs were grown in Vero cells or C6/36 cells in Dulbecco's modified minimal essential medium (DMEM) containing $5 \%$ fetal bovine serum (FBS) and penicillin-streptomycin.

The four vaccine viruses were generated from cDNA clonederived DENV-2 VV45R virus (based on the genome of DENV-2 PDK-53), and the DENV-2 PDK-53-based chimeras expressing the prM and E genes of DENV-1 16007, DENV-3 16562, or DENV-4 1036. The construction and characterization of these viruses has been previously reported $(10,19)$.

\section{NON-HUMAN PRIMATES}

Twelve adult male, DENV seronegative cynomolgus macaques originating from Vietnam were used. The animals were placed in quarantine for 30 days prior to study start. The study was conducted at the Charmany Instructional Facility of the University of Wisconsin, Madison, WI, USA in compliance with the Animal Care Regulations.

\section{EXPERIMENTAL ANIMAL STUDY DESIGN}

In this study, groups of monkeys $(n=3)$ received the TDV formulated into either $0.5 \mathrm{ml}$ for SC administration or $0.1 \mathrm{ml}$ for ID delivery using the $\mathrm{PhJ}$ device. Each full dose of the tetravalent vaccine used in this study contained $2 \times 10^{4}$ PFU of TDV- 1 , $5 \times 10^{4} \mathrm{PFU}$ of TDV-2, $1 \times 10^{5} \mathrm{PFU}$ of TDV- 3 , and $3 \times 10^{5} \mathrm{PFU}$ of TDV-4 vaccine viruses. This vaccine constitutes the clinical trial material used for two Phase 1 studies conducted in USA and Colombia, as well as Phase 2 studies currently ongoing in endemic areas.

Each animal in the first two groups received two injections on day 0 , one in each arm ID or SC. A third group of animals was injected SC on day 0 and 53 using the PhJ device. Control animals received $\mathrm{PBS}$ via the ID route using $\mathrm{PhJ}$. On day 90, all animals were challenged SC with $10^{5} \mathrm{PFU}$ of DENV-2 (NGC strain) using N-S. Serum samples were collected on days $0,3,5,7,10,12,14$, $53,64,67$, and 88 post-primary immunization to analyze vaccine viremia, and days $91,93,95,97,99,101,102$, and 104 to analyze DENV-2 NGC viremia after challenge. Serum samples also were collected on days $0,30,53,75,88$, and 104 to determine neutralizing antibody titers to each serotype. PBMCs from group 2 and 4 were collected to measure $\mathrm{T}$ cell responses.

\section{SERUM VIRAL RNA}

Viral RNA in serum samples was measured using a quantitative reverse transcription-polymerase chain reaction (qRT-PCR) as follows. Viral RNA was extracted from $140 \mu$ l of each individual serum sample using a QIAamp viral RNA kit (Qiagen, Valencia, CA, USA) and eluted in $60 \mu \mathrm{l}$ elution buffer. Viral RNA standards, used to create a standard curve in all qRT-PCR assays, were in vitro transcribed from cDNA clones and quantified as previously described (20). E-gene primers, TaqMan probes, and RNA standards were serotype specific (Table 1). Using a different fluorophore for each serotype specific probe (sequences available upon request), qRT-PCRs were performed in duplex: one reaction quantified TDV-1 and TDV-2 vaccine viruses while a separate one quantified TDV-3 and TDV-4 viruses RNA. Following DENV-2 NGC challenge, viral RNA was quantified in a singleplex qRTPCR. All qRT-PCR reactions were performed in a final volume of $25 \mu$ l using the QuantiTect Virus + ROX Vial Kit (Qiagen, Valencia, CA, USA). The reactions contained $5 \mu$ l extracted RNA, $0.4 \mu \mathrm{M}$ of each primer, and $0.2 \mu \mathrm{M}$ probe. The reaction was conducted in the iQ5 iCycler system (Bio-Rad Laboratories) using the following cycle; 1 cycle of $50^{\circ} \mathrm{C}$ for $20 \mathrm{~min}$ at room temperature (RT), 1 cycle of $95^{\circ} \mathrm{C}$ for $5 \mathrm{~min}$, and 50 cycles of $95^{\circ} \mathrm{C}$ for $15 \mathrm{~s}$. Limit of detection for the qRT-PCR was determined for each viral RNA standard by creating a standard curve consisting of nine replicates per dilution. While the sensitivity reached 3.9 copies/reaction $\left(\sim 2.7 \log _{10}\right.$ copies $/ \mathrm{ml}), 3.6 \log _{10}$ copies $/ \mathrm{ml}$ met the criteria of a $100 \%$ detection

Table 1 | E protein primers used in this study.

\section{Sequence}

\section{ANTI-SENSE PRIMERS}

CD1-1593 CAA GGC AGT GGT AAG TCT AGA AAC C

CD2-2116 TCT TAA ACC AGT TGA GCTTCA GTT GT

CD3-2000 CCA CTG GATTGG CTGTGATC

CD4-843 GCG CGA ATC CTG GGTTT

\section{SENSE PRIMERS}

D1-1459 GACCGACTACGGAACCCTTACAT

D2-1929 TCC ATG CAA GAT CCC TTT TGA

D3-1872 CGC AGC ATG GGA CAATAC TC

D4-637 GCTGGTGCAATCTCACGTCTA

PROBES

CD11519P CTC GTT AAA ATC TAG CCC TGT CCT AGG TGA ACA AT - FAM

D2-2000P ACC CAA TTG TGA CAG AAA AAG ATA GCC CAG TC - TET

D3-1914P AAG ATG CAC CCT GCA AGA TTC CTTTCT C - TET

CD4-699P TCC GTT CTC CGC TCT GGG TGC AT - FAM 
rate as well as a low $(\leq 0.5)$ cycle threshold standard deviation of the replicates and was used as a cutoff for the assay.

\section{MICRONEUTRALIZATION ASSAY}

Serum samples were incubated at $56^{\circ} \mathrm{C}$ for $30 \mathrm{~min}$ to inactivate complement and possible adventitious agents. Heat-inactivated serum samples then were tested for neutralizing activity using a viral immunofocus reduction microneutralization assay and analyzed by an AID ELISpot reader (San Diego, CA, USA). Briefly, 96-well tissue culture plates were seeded with Vero cells at a density of $1.3 \times 10^{5} \mathrm{cells} / \mathrm{ml}$ in $100 \mu \mathrm{l} /$ well. Cells were grown at $37^{\circ} \mathrm{C}$ in a $5 \% \mathrm{CO}_{2}$ incubator for $48 \mathrm{~h}$. Twofold serial serum dilutions were prepared in a separate 96-well plate and then mixed with virus suspension containing $100 \mathrm{PFU}$ followed by incubation at $4^{\circ} \mathrm{C}$ for $13-15 \mathrm{~h}$. Culture medium was discarded from the Vero cell plates and then $30 \mu \mathrm{l}$ of the serum-virus mixture was added to each well in triplicate followed by incubation at $37^{\circ} \mathrm{C}$ for $2 \mathrm{~h}$. Control positive and negative serum samples were also included. An overlay medium with $1.2 \%$ carboxymethyl cellulose was added ( $100 \mu \mathrm{l} /$ well) and cells were incubated as above for 2 days for DENV-4, 2.5 days for DENV-1 and -3, and 3 days for DENV-2. After incubation, the overlay was removed and cells were fixed with $85 \%$ cold acetone for $10 \mathrm{~min}$ at RT. Acetone was then discarded and plates were stored at $-20^{\circ} \mathrm{C}$ until further use. Prior to staining, plates were equilibrated to RT, and washed three times with PBS to rehydrate the cells and to remove any residual overlay. Rabbit anti-DENV polyclonal antibody diluted (1:1000) in PBS$\mathrm{T}$ containing $2.5 \%(\mathrm{w} / \mathrm{v})$ dry milk powder was added, and plates were incubated at $37^{\circ} \mathrm{C}$ for $2 \mathrm{~h}$. Plates were washed three times with PBS-T and incubated with anti-rabbit antibody conjugated with horse radish peroxidase (HRP) at $37^{\circ} \mathrm{C}$ for $2 \mathrm{~h}$. Finally, plates were washed three times with PBS-T and incubated with the substrate (3-amino-9-ethylcarbozole) for 10-30 min or until plaques were visible. The plates were then washed with water and air-dried. The viral immunofoci were quantified on an ELISpot reader. Fifty percent of the average number of foci in the negative control serum defined the cutoff point. The serum dilution closest to the cutoff was recorded as the reciprocal neutralizing titer.

\section{INTRACELLULAR CYTOKINE SECRETION ASSAY BY FLOW CYTOMETRY}

To assess the functional capability of TDV-elicited dengue-specific T cells, we performed intracellular cytokine staining (ICS) assays. For positive control, we used Staphylococcus Enterotoxin B (SEB) stimulation, for negative control, we used tissue culture medium devoid of added stimulatory peptides. Peptide arrays used in this study (Table 2) were obtained from the National Institute of Allergy and Infectious Diseases Biodefense and Emerging Infections Research Resources Repository (BEI Resources). Individual peptides were prepared as $10 \mathrm{mM}$ stock solutions for NS1 and NS5 and $15 \mathrm{mM}$ for NS5 peptides. An aliquot of $0.5-1.5 \times 10^{6}$ $\mathrm{PBMC}$ in $200 \mu \mathrm{l}$ total volume was incubated with peptides at $5 \mu \mathrm{M}$ final concentration in the presence of anti-CD28 (clone L293), anti-CD49d (clone 9F10), and CD107a PE (clone H4A3) antibodies, and $1 \mu \mathrm{g}$ per test of Brefeldin A (Sigma-Aldrich, St. Louis, MO, USA) and Golgi Stop at $37^{\circ} \mathrm{C}$ in a $5 \% \mathrm{CO}_{2}$ incubator overnight. Cells were stained for the surface expression of CD3 (PE-CF594 clone SP34-2), CD4 (PerCP-Cy5.5-conjugated
Table 2 | Peptide arrays

\begin{tabular}{lccc}
\hline Serotype/peptides & aa. Number & Virus strain & Cat. no. (NBI) \\
\hline DENV-2 NS1 & 47 & New Guinea C & NR-508 \\
DENV-2 NS3 & 83 & New Guinea C & NR-509 \\
DENV-2 NS5 & 155 & New Guinea C & NR-2746 \\
DENV-4 NS3 & 106 & Singapore/8976/1995 & NR-2756 \\
DENV-4 NS5 & 156 & Singapore/8976/1995 & NR-4205 \\
\hline
\end{tabular}

clone L200), CD8 (Pacific Blue-conjugated clone RPA-T8), and live/dead fixable Aqua Dead Cell stain (Invitrogen), washed twice with FACS buffer, and fixed with 2\% paraformaldehyde. Cells were then permeabilized with $0.1 \%$ saponin buffer, intracellularly stained for IFN- $\gamma$ (Alexa Fluor 700-conjugated clone 4S.B3), TNF$\alpha$ (FITC-conjugated clone Mab11), and IL-2 (APC-conjugated clone MQ1-17H12), washed twice with saponin buffer, and fixed with $2 \%$ paraformaldehyde. All fluorescent-labeled antibodies and reagents were purchased from BD Biosciences except when mentioned. Sample data were acquired on a SORP BD LSR II equipped with a $50 \mathrm{~mW} 405$ violet, a $100 \mathrm{~mW} 488$ blue, and a $50 \mathrm{~mW} 640$ red laser (BD Biosciences) using FACSDiva version 6.1 acquisition software. We collected approximately 150-300 thousand events in the lymphocyte gate defined by forward and side scatter parameters. Data were analyzed by FlowJo ${ }^{\text {TM }}$ 9.4.2 software (Tree Star, Inc., Ashland, OR, USA). Background values from peptide stimulated values were subtracted. The frequency of cytokine-positive $\mathrm{T}$ cells was presented as the percentage of gated $\mathrm{CD} 4^{+}$or $\mathrm{CD} 8^{+} \mathrm{T}$ cells.

\section{RESULTS}

\section{VACCINE VIRAL RNA FOLLOWING IMMUNIZATION}

Following immunization, the presence of vaccine viral RNA in the serum was monitored by qRT-PCR of sequential bleeds collected over a period of 14 days post-primary immunization. TDV induced detectable TDV-2 virus replication from day 5 to 14 for animals injected SC, and day 7-12 for those injected ID (Table 3). No viral RNA from TDV-1, -3 , and -4 vaccine viruses was detected in any of the groups on samples collected over a period of 14 days post-primary immunization.

\section{NEUTRALIZING ANTIBODY RESPONSES ELICITED BY VACCINATION}

The individual neutralizing antibody titers and kinetics of antibody responses elicited by TDV are shown in Table 4. Overall, administration of the vaccine by the ID or SC routes using the RIS ( 0,0 vaccination schedule) induced comparable neutralizing antibody titers to all four serotypes. In all cases, the dominant neutralizing antibody response was to DEN-2, whereas TDV-4 was the least immunogenic component of the tetravalent vaccine formulation.

\section{CHARACTERIZATION OF T CELL RESPONSES ELICITED BY THE VACCINE}

To determine the target proteins of the $\mathrm{T}$ cell response elicited by TDV, PBMCs from immunized animals (group 2) collected on day 53 post-priming were restimulated in vitro with pools of peptides encompassing the entire sequence of DENV-2 NS1, NS3, and NS5 proteins (Table 2). As shown in Figure $1, \mathrm{CD}^{+} \mathrm{T}$ cells predominantly targeted the NS1 protein and to a lesser extent the NS3 
and NS5 proteins, producing IFN- $\gamma$ (a), IL-2 (b), and TNF- $\alpha$ (c). The vaccine also elicited $\mathrm{CD} 8^{+} \mathrm{T}$ cells mainly recognizing epitopes from the NS1 protein and to a lesser degree from NS3 and NS5 proteins (Figure 2). In particular, responses to the NS1 were characterized by the production of IFN- $\gamma$ (a), IL-2 (b), TNF- $\alpha$ (c), and expression of $\mathrm{CD} 107 \mathrm{a}^{+}$marker $(\mathrm{d})$. In contrast, $\mathrm{T}$ cell responses in PBS immunized animals (group 4) were comparatively very low (Figures 1 and 2). In addition, vaccine-specific $\mathrm{CD} 8^{+}$IFN- $\gamma$ producing T cells were cross-reactive with epitopes from the NS3 and NS5 non-structural proteins of DENV-4 (Figure 3A) and were shown to express the CD107a ${ }^{+}$marker (Figure 3B). A similar pattern of $\mathrm{T}$ cell responses recognizing predominantly the NS1 protein with no significant differences in frequencies of $\mathrm{CD}^{+}$and $\mathrm{CD} 8^{+}$ $\mathrm{T}$ cells were also measured in group 3 (data not shown).

Table 3 |TDV-2 virus RNA detected in the serum after primary immunization with TDV

\begin{tabular}{|c|c|c|c|c|c|c|}
\hline \multirow[t]{2}{*}{ Group } & \multirow{2}{*}{$\begin{array}{l}\text { Dosing } \\
\text { schedule }\end{array}$} & \multicolumn{5}{|c|}{ No. of animals positive for viral RNA } \\
\hline & & Day 5 & Day 7 & Day 10 & Day 12 & Day 14 \\
\hline 1 & $\begin{array}{l}\text { TDV PhJ/ID } \\
\text { (day 0, 0) }\end{array}$ & - & $\begin{array}{c}1 / 3 \\
(4.8)\end{array}$ & $\begin{array}{c}3 / 3 \\
(4.5-4.9)\end{array}$ & $\begin{array}{c}2 / 3 \\
(3.9-4.3)\end{array}$ & - \\
\hline 2 & $\begin{array}{l}\text { TDV PhJ/SC } \\
(\text { day } 0,0)\end{array}$ & $\begin{array}{c}1 / 3 \\
(3.8)^{a}\end{array}$ & $\begin{array}{c}3 / 3 \\
(4.0-4.3)\end{array}$ & $\begin{array}{c}3 / 3 \\
(3.7-4.7)\end{array}$ & $\begin{array}{c}1 / 3 \\
(4.0)\end{array}$ & - \\
\hline 3 & $\begin{array}{l}\text { TDV PhJ/SC } \\
\text { (day } 0,60 \text { ) }\end{array}$ & $\begin{array}{c}1 / 3 \\
(3.8)\end{array}$ & $\begin{array}{c}3 / 3 \\
(4.5-5.4)\end{array}$ & $\begin{array}{c}3 / 3 \\
(3.8-5.3)\end{array}$ & $\begin{array}{c}3 / 3 \\
(3.2-4.8)\end{array}$ & $\begin{array}{c}2 / 3 \\
(3.7-5.0)\end{array}$ \\
\hline 4 & $\begin{array}{l}\text { PBS PhJ/ID } \\
\text { (day 0,60) }\end{array}$ & - & - & - & - & - \\
\hline
\end{tabular}

Results are averages from duplicate or triplicate data.

Samples with titers $<3.6 \log _{10}$ copies $/ \mathrm{m} /$ were considered negative.

${ }^{a}$ Data in parenthesis represent range of titers in $\log _{10}$ copies $/ \mathrm{ml}$.

\section{PROTECTION FROM DENV-2 NGC CHALLENGE}

Since TDV-2 constitutes the backbone of TDV in this study, we examined the protective efficacy of this vaccine against challenge with DENV-2 NGC strain. Upon DENV-2 NGC challenge viral RNA was detected in the serum of all mock-immunized animals (Table 4). None of the vaccinated animals displayed DENV-2 NGC RNA. When the neutralizing antibody responses to DENV-2 were compared before and after challenge there was no significant increase in antibody titers in all vaccinated groups suggesting that DENVax elicits sterilizing immunity to DENV-2 (Table 5). In contrast, mock vaccinated animals developed a strong anti-DEN-2 neutralizing antibody response after challenge (Table 5).

\section{DISCUSSION}

To facilitate global dengue prevention and control through effective vaccination, a simple and practical method of administration is highly desirable. This study examined several aspects of vaccine delivery in the NHP model. In particular, we compared immune responses elicited by the SC and ID routes using a needle-free disposable syringe jet injection (DSJI) delivery device and assessed RIS as an alternative to the traditional prime/boost vaccination schedule. Immunization with TDV resulted in the detection of only TDV-2 virus RNA in the serum of vaccinated animals. This is consistent with our previous observations in the NHP model (17). The absence of post-boost viremia in animals that received a prime and booster immunization $(0,60)$ suggests that priming with the tetravalent vaccine was effective in eliciting immune responses able to reduce and control viral replication upon secondary exposure.

The use of a needle-free DSJI delivery device to administer TDV provided strong evidences suggesting the feasibility of an alternate approach to ID administration. Indeed, measurement of neutralizing antibody responses demonstrated that the vaccine was highly immunogenic. However, responses were unbalanced with anti-DEN-2 neutralizing titers being the highest and those against DEN-4 the lowest. This finding is consistent with previous

Table 4 | Kinetics of neutralizing antibody responses in animals vaccinated with TDV SC or ID using the PharmaJet device.

\begin{tabular}{|c|c|c|c|c|c|c|c|c|c|c|c|c|c|}
\hline \multirow[t]{2}{*}{ NHP ID } & \multirow[t]{2}{*}{ Vaccine regimen } & \multicolumn{4}{|c|}{ Day 30} & \multicolumn{4}{|c|}{ Day 53} & \multicolumn{4}{|c|}{ Day 88} \\
\hline & & Day 1 & Day 2 & Day 3 & Day 4 & Day 1 & Day 2 & Day 3 & Day 4 & Day 1 & Day 2 & Day 3 & Day 4 \\
\hline CY0503 & $0,0 \mathrm{PhJ} / \mathrm{ID}$ & 40 & 1280 & 160 & 20 & 160 & 1280 & 40 & 10 & 80 & 5120 & 20 & 40 \\
\hline CY0504 & & 80 & 640 & 40 & 10 & 40 & 2560 & 40 & 5 & 80 & 2560 & 20 & 40 \\
\hline \multirow[t]{2}{*}{ CY0505 } & & 320 & 1280 & 2560 & 320 & 160 & 640 & 640 & 160 & 80 & 640 & 160 & 40 \\
\hline & GMT & 101 & 1016 & 254 & 40 & 101 & 1280 & 101 & 20 & 80 & 2032 & 40 & 40 \\
\hline CY0473 & $0,0 \mathrm{PhJ} / \mathrm{SC}$ & 2560 & 10,240 & 160 & 40 & 640 & 5120 & 80 & 20 & 320 & 1280 & 40 & 20 \\
\hline CY0474 & & 1280 & 320 & 1280 & 160 & 640 & 640 & 640 & 160 & 320 & 320 & 160 & 80 \\
\hline \multirow[t]{2}{*}{ CY0475 } & & 640 & 320 & 640 & 320 & 640 & 320 & 320 & 80 & 160 & 320 & 160 & 160 \\
\hline & GMT & 1280 & 1016 & 508 & 127 & 640 & 1016 & 254 & 64 & 254 & 508 & 101 & 64 \\
\hline CY0493 & 0, $60 \mathrm{PhJ} / \mathrm{SC}$ & 160 & 2560 & 160 & 20 & 80 & 2560 & 10 & 20 & 320 & 2560 & 80 & 40 \\
\hline CY0494 & & 320 & 640 & 640 & 160 & 320 & 640 & 320 & 10 & 80 & 640 & 160 & 80 \\
\hline \multirow[t]{2}{*}{ CY0495 } & & 640 & 2560 & 320 & 40 & 640 & 2560 & 40 & 80 & 1280 & 2560 & 160 & 40 \\
\hline & GMT & 320 & 1613 & 320 & 50 & 254 & 1613 & 50 & 25 & 320 & 1613 & 127 & 50 \\
\hline
\end{tabular}

GMT, geometric mean titer. 

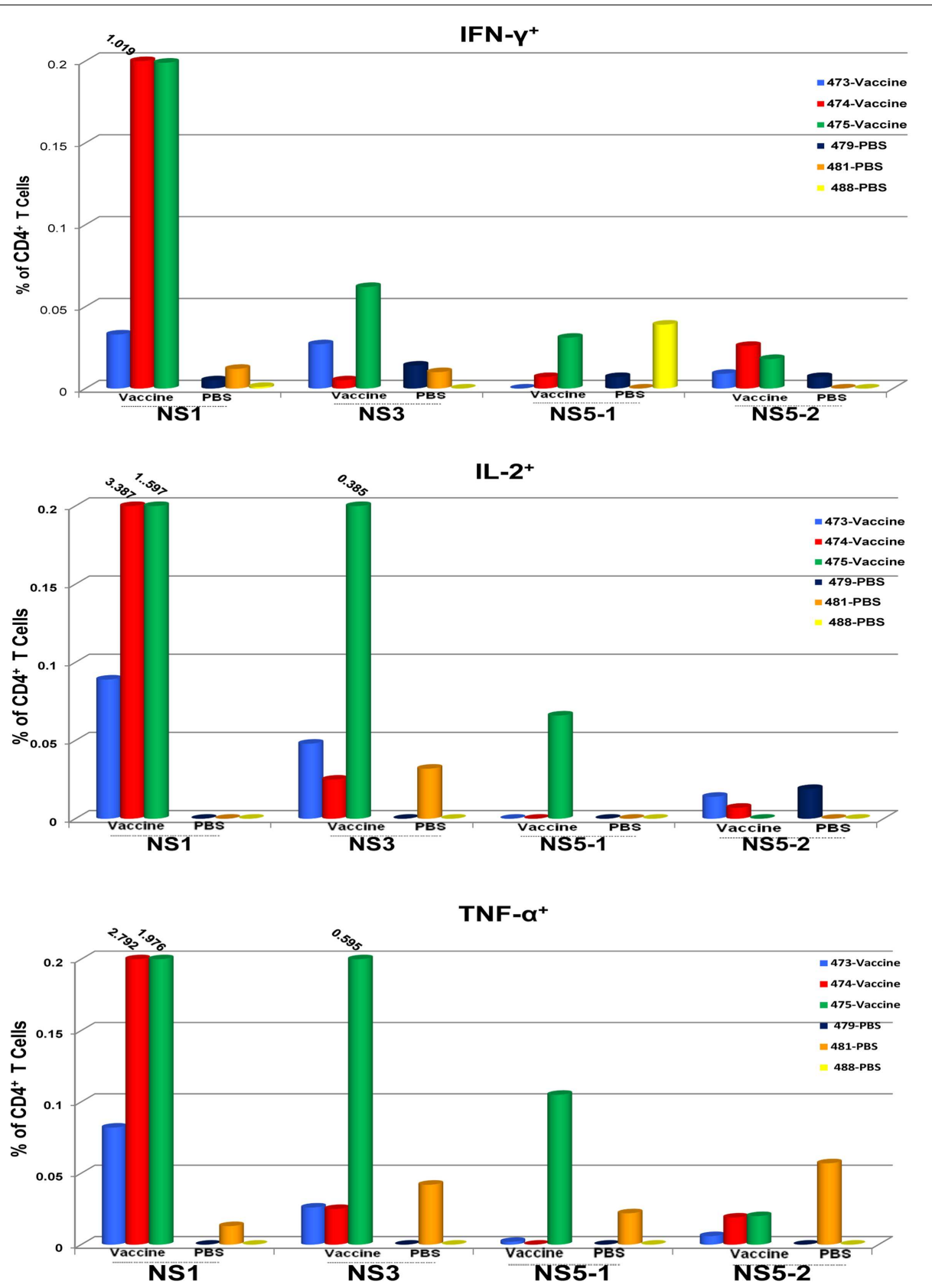

FIGURE 1 | $\mathrm{CD4}^{+} \mathrm{T}$ cell responses to TDV target the non-structural proteins of TDV-2. Responses are shown as percentage of cytokine-positive T cells from DENV-2 peptide arrays stimulated PBMCs with the background percentage of cytokine-positive T cells in medium only treated cells subtracted. Peptide arrays for NS5 were split into two pools; NS5-1 and NS5-2. PBMCs from PBS immunized animals were used as controls. observations made in preclinical animal models $(10,16,17)$ and in Phase 1 clinical trials conducted in the USA and Colombia (Osorio et al., and George et al., in preparation) using $\mathrm{N}-\mathrm{S}$ delivery with a prime/boost schedule. Since DENV-2 is the most frequent serotype implicated in DHF/DSS in secondary DENV infections (21) it could be argued that immunization with TDV could be advantageous in conferring protection against this serotype. When antibodies induced by the 0,0 and 0,53 vaccination schedule by the SC route were compared, the overall titers to all four
DENV serotypes were similar. This suggests that the $0,0 \mathrm{immu-}$ nization schedule can efficiently prime the immune system for tetravalent responses, which can be sustained at high levels up to 3 months. Therefore, this vaccination schedule could be especially advantageous for travelers in endemic areas.

In the context of vaccination, it is critical to characterize the profile of $\mathrm{T}$ cell responses and determine the target proteins of this response. The recent analysis of $\mathrm{T}$ cell responses from a large cohort of DENV-infected individuals has highlighted the role of T 

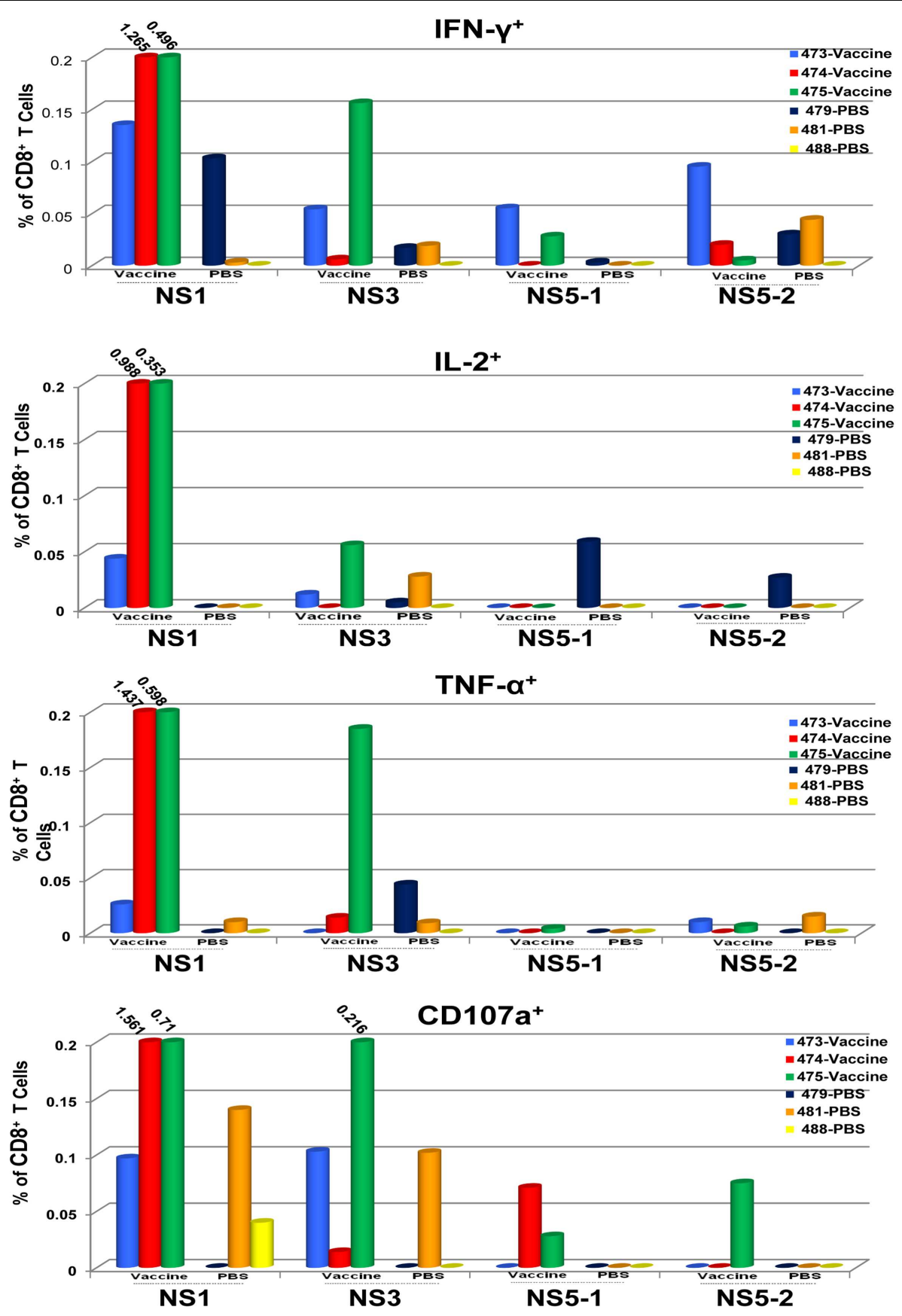

FIGURE 2 | $\mathrm{CDB}^{+} \mathrm{T}$ cell responses to TDV target the non-structural proteins of TDV-2. Responses are shown as percentage of cytokine-positive $T$ cells from DENV-2 peptide arrays stimulated PBMCs with the background percentage of cytokine-positive T cells in medium only treated cells subtracted. Peptide arrays for NS5 were split into two pools; NS5-1 and NS5-2. PBMCs from PBS immunized animals were used as controls. cells in prevention of development of disease (22). In this study, we demonstrated that SC PhJ delivery of TDV using RIS is effective in inducing $\mathrm{CD}^{+}{ }^{+}$and $\mathrm{CD} 8^{+} \mathrm{T}$ cells. Both $\mathrm{T}$ cell subsets produced IFN- $\gamma$, TNF- $\alpha$, and IL-2 highlighting their Th1-type immune profile. In addition, using peptide arrays we demonstrated that they predominantly recognized sequences from the NS1 protein and to a lesser extent from NS3 of DENV-2. Moreover, we observed that the TDV-2 backbone elicited cross-reactive T cell responses to the highly conserved NS proteins of DENV-4. Similarly, we have observed cross-reactivity with the NS proteins of DENV-1 and $\mathrm{E}$ proteins of each serotype (data not shown). Overall, these findings highlight the potential of TDV-2 backbone to elicit a broad range of cross-reactive $\mathrm{T}$ cell responses to all four DENV serotypes. 


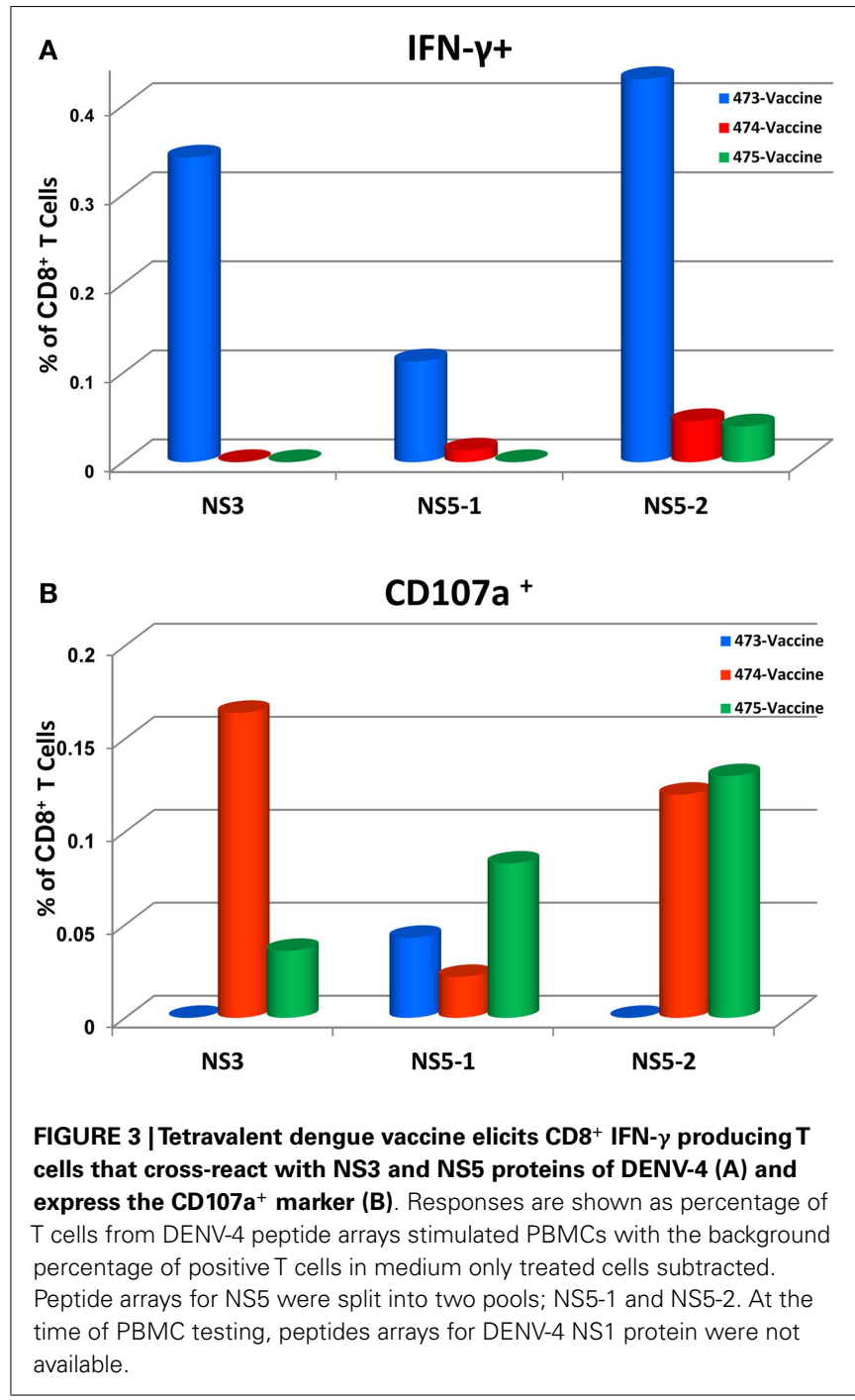

The protective efficacy of TDV was assessed against challenge with DENV-2 NGC. All vaccinated animals were protected against DENV-2 NGC as shown by the lack of viral RNA post-challenge, whereas control animals were positive for viral RNA. At the time of challenge, animals from all treatment groups had high levels of anti-DEN-2 neutralizing antibodies (GMT > 300) and their titers were not boosted following challenge. This suggests that the vaccine elicited sterilizing immunity against DENV-2 NGC. Although this study was designed to measure efficacy of TDV using a short-term immunization and challenge protocol, we currently plan to address the longevity of the neutralizing antibody response to vaccination and its impact on protection against challenge with all DENV serotypes. Moreover, the recently published data of the first clinical proof-of-concept efficacy study of a TDV demonstrated safety but only partial efficacy against some but not all DENV viruses, and showed that the standard plaque reduction neutralization test used as the primary immune correlate failed to predict efficacy (23). Therefore, further studies are needed to measure neutralization using different cell substrates $(24,25)$. Despite the limitations of the NHP model to mimic human disease, efficacy studies based on the presence of viremia as an end point can provide critical information about the protective capacity of candidate DENV vaccines since there are several lines of evidences supporting the view that the severity of disease correlates with increased levels of viremia $(26,27)$. In conclusion, the delivery of our live-attenuated TDV using the PhJ needle-free DSJI technology has the potential to impact future mass vaccination campaigns.

\section{AUTHOR CONTRIBUTIONS}

Conceived and designed the experiments: Dan T. Stinchcomb, Jorge E. Osorio, Aurelia A. Haller, Charalambos D. Partidos, and Claire Y.-H. Huang. Performed the experiments: Yuping Ambuel, Ginger Young, Joanna Paykel, Kim L. Weisgrau, Michael Royals, and Joseph N. Brewoo. Managed the NHP facility: Saverio Capuano. Analyzed the data: Yuping Ambuel, Eva G. Rakasz,

Table 5 | Protection of TDV vaccinated NHPs from DENV-2 NGC challenge.

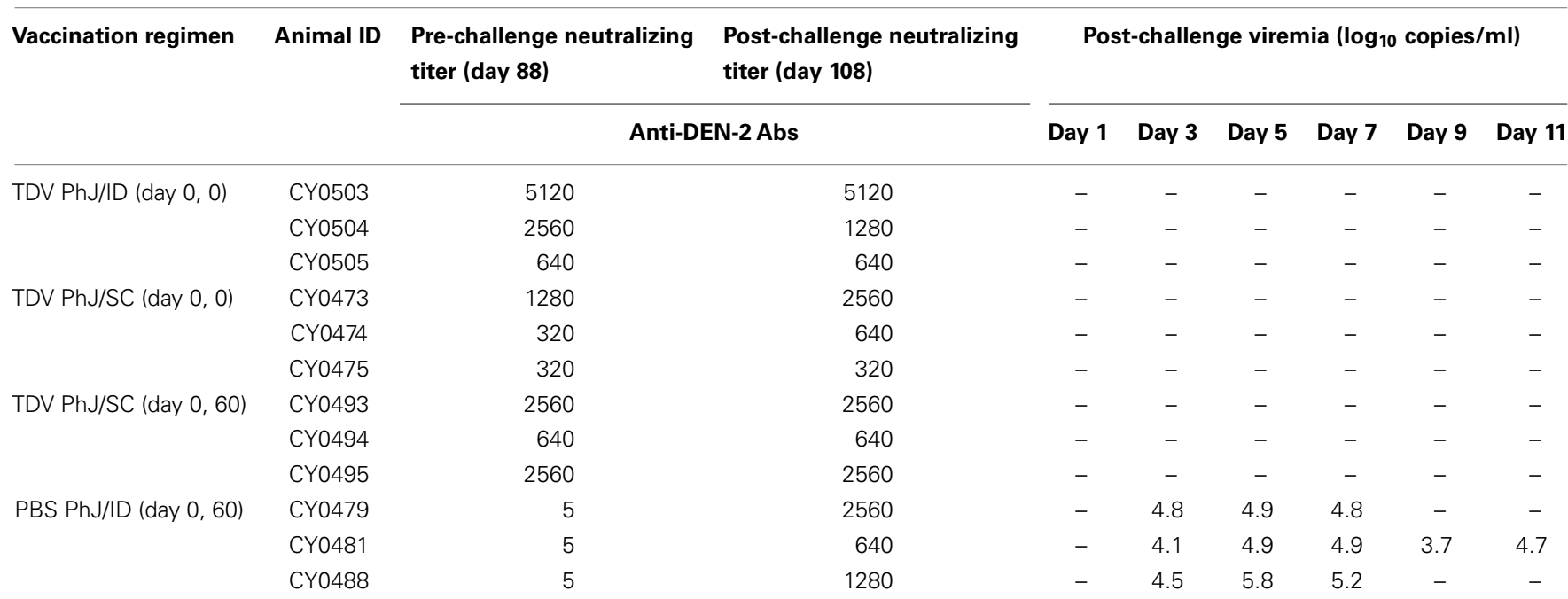


Kim L. Weisgrau, and Charalambos D. Partidos. Wrote the paper: Charalambos D. Partidos.

\section{ACKNOWLEDGMENTS}

This project has been funded in part with Federal funds from the National Institute of Allergy and Infectious Diseases, National Institutes of Health, Department of Health and Human Services, under Contract No. HHSN272201000034C.

\section{REFERENCES}

1. Guzman MG, Halstead SB, Artsob H, Buchy P, Farrar J, Gubler DJ, et al. Dengue: a continuing global threat. Nat Rev Microbiol (2010) 8:S7-16. doi:10.1038/ nrmicro2460

2. Bhatt S, Gething PW, Brady OJ, Messina JP, Farlow AW, Moyes CL, et al. The global distribution and burden of dengue. Nature (2013) 496:504-7. doi: $10.1038 /$ nature 12060

3. Gubler DJ. Dengue, urbanization and globalization: the unholy trinity of the 21(st) century. Trop Med Health (2011) 39:3-11. doi:10.2149/tmh.2011-S05

4. Martina BE, Koraka P, Osterhaus AD. Dengue virus pathogenesis: an integrated view. Clin Microbiol Rev (2009) 22:564-81. doi:10.1128/CMR.00035-09

5. Whitehorn J, Simmons CP. The pathogenesis of dengue. Vaccine (2011) 29:7221-8. doi:10.1016/j.vaccine.2011.07.022

6. Halstead SB, Mahalingam S, Marovich MA, Ubol S, Mosser DM. Intrinsic antibody-dependent enhancement of microbial infection in macrophages: disease regulation by immune complexes. Lancet Infect Dis (2010) 10:712-22. doi:10.1016/S1473-3099(10)70166-3

7. Rothman AL. Dengue: defining protective versus pathologic immunity. J Clin Invest (2004) 113:946-51. doi:10.1172/JCI21512

8. Rothman AL. T lymphocyte responses to heterologous secondary dengue virus infections. Ann N Y Acad Sci (2009) 1171:E36-41. doi:10.1111/j.1749-6632. 2009.05055.x

9. Whitehead SS, Blaney JE, Durbin AP, Murphy BR. Prospects for a dengue virus vaccine. Nat Rev Microbiol (2007) 5:518-28. doi:10.1038/nrmicro1690

10. Huang CY-H, Butrapet S, Tsuchiya KR, Bhamarapravati N, Gubler DJ, Kinney RM. Dengue 2 PDK-53 virus as a chimeric carrier for tetravalent dengue vaccine development. J Virol (2003) 77:11436-47. doi:10.1128/JVI.77.21.11436-11447. 2003

11. Huang CY-H, Butrapet S, Pierro DJ, Chang GJJ, Hunt AR, Bhamarapravati N, et al. Chimeric dengue type 2 (vaccine strain PDK-53)/dengue type 1 virus as a potential candidate dengue type 1 virus vaccine. J Virol (2000) 74:3020-8. doi:10.1128/JVI.74.7.3020-3028.2000

12. Kinney RM, Butrapet S, Chang GJ, Tsuchiya KR, Roehrig JT, Bhamarapravati N, et al. Construction of infectious cDNA clones for dengue 2 virus: strain 16681 and its attenuated vaccine derivative, strain PDK-53. Virology (1997) 230:300-8. doi:10.1006/viro.1997.8500

13. Butrapet S, Huang CY, Pierro DJ, Bhamarapravati N, Gubler DJ, Kinney RM. Attenuation markers of a candidate dengue type 2 vaccine virus, strain 16681 (PDK-53) are defined by mutations in the $5^{\prime}$ noncoding region and nonstructural proteins 1 and 3. J Virol (2000) 74:3011-9. doi:10.1128/JVI.74.7.30113019.2000

14. Vaughn DW, Hoke CH Jr., Yoksan S, LaChance R, Innis BL, Rice RM, et al. Testing of a dengue 2 live-attenuated vaccine (strain 16681 PDK 53) in ten American volunteers. Vaccine (1996) 14:329-36. doi:10.1016/0264-410X(95) 00167-Y

15. Bhamarapravati N, Yoksan S, Chayaniyayothin T, Angsubphakorn S, Bunyaratvej A. Immunization with a live attenuated dengue-2-virus candidate vaccine (16681-PDK 53): clinical, immunological and biological responses in adult volunteers. Bull World Health Organ (1987) 65:189-95.

16. Brewoo JN, Kinney RM, Powell TD, Arguello JJ, Silengo SJ, Partidos CD, et al. Immunogenicity and efficacy of chimeric dengue vaccine (DENVax) formulations in interferon-deficient AG129 mice. Vaccine (2012) 30:1513-20. doi:10.1016/j.vaccine.2011.11.072
17. Osorio JE, Brewoo JN, Silengo SJ, Arguello J, Moldovan IR, Tary-Lehmann M, et al. Efficacy of a tetravalent chimeric dengue vaccine (DENVax) in Cynomolgus macaques. Am J Trop Med Hyg (2011) 84:978-87. doi:10.4269/ajtmh.2011.100592

18. Lambert PH, Laurent PE. Intradermal vaccine delivery: will new delivery systems transform vaccine administration? Vaccine (2008) 26:3197-208. doi:10. 1016/j.vaccine.2008.03.095

19. Huang CY, Kinney RM, Livengood JA, Bolling B, Arguello JJ, Luy BE, et al. Genetic and phenotypic characterization of manufacturing seeds for a tetravalent dengue vaccine (DENVax). PLoS Negl Trop Dis (2013) 7:e2243. doi:10.1371/ journal.pntd.0002243

20. Butrapet S, Kinney RM, Huang CY. Determining genetic stability of chimeric dengue vaccine candidates based on dengue 2 PDK-53 virus by sequencing and quantitative TaqMAMA. JVirol Methods (2006) 131:1-9. doi:10.1016/j.jviromet. 2005.06.019

21. Fried JR, Gibbons RV, Kalayanarooj S, Thomas SJ, Srikiatkhachorn A, Yoon IK, et al. Serotype-specific differences in the risk of dengue hemorrhagic fever: an analysis of data collected in Bangkok, Thailand from 1994 to 2006. PLoS Negl Trop Dis (2010) 4:e617. doi:10.1371/journal.pntd.0000617

22. Weiskopf D, Angelo MA, de Azeredo EL, Sidney J, Greenbaum JA, Fernando $\mathrm{AN}$, et al. Comprehensive analysis of dengue virus-specific responses supports an HLA-linked protective role for CD8+ T cells. Proc Natl Acad Sci U S A (2013) 110:E2046-53. doi:10.1073/pnas.1305227110

23. Sabchareon A, Wallace D, Sirivichayakul C, Limkittikul K, Chanthavanich P, Suvannadabba S, et al. Protective efficacy of the recombinant, live-attenuated, CYD tetravalent dengue vaccine in Thai schoolchildren: a randomised, controlled phase 2b trial. Lancet (2012) 380:1559-67. doi:10.1016/S0140-6736(12) 61428-7

24. Halstead SB. Identifying protective dengue vaccines: guide to measuring an empirical process. Vaccine (2013) 31:4501-7. doi:10.1016/j.vaccine.2013.06. 079

25. Oliphant T, Nybakken GE, Engle M, Xu Q, Nelson CA, Sukupolvi-Petty S, et al. Antibody recognition and neutralization determinants on domains I and II of West Nile Virus envelope protein. J Virol (2006) 80:12149-59. doi:10.1128/JVI.01732-06

26. Vaughn DW, Green S, Kalayanarooj S, Innis BL, Nimmannitya S, Suntayakorn S, et al. Dengue in the early febrile phase: viremia and antibody responses. J Infect Dis (1997) 176:322-30. doi:10.1086/514048

27. Vaughn DW, Green S, Kalayanarooj S, Innis BL, Nimmannitya S, Suntayakorn S, et al. Dengue viremia titer, antibody response pattern, and virus serotype correlate with disease severity. J Infect Dis (2000) 181:2-9. doi:10.1086/ 315215

Conflict of Interest Statement: Yuping Ambuel, Ginger Young, Joseph N. Brewoo, Joanna Paykel, Aurelia A. Haller, Dan T. Stinchcomb, Charalambos D. Partidos, and Jorge E. Osorio are affiliated with Takeda Vaccine, Inc., Michael Royals is affiliated with PharmaJet, Inc. The other authors declare no conflicts of interest.

Received: 14 March 2014; accepted: 20 May 2014; published online: 05 June 2014. Citation: Ambuel Y, Young G, Brewoo JN, Paykel J, Weisgrau KL, Rakasz EG, Haller AA, Royals M, Huang CY-H, Capuano S, Stinchcomb DT, Partidos CD and Osorio JE (2014) A rapid immunization strategy with a live-attenuated tetravalent dengue vaccine elicits protective neutralizing antibody responses in non-human primates. Front. Immunol. 5:263. doi: 10.3389/fimmu.2014.00263

This article was submitted to Microbial Immunology, a section of the journal Frontiers in Immunology.

Copyright (c) 2014 Ambuel, Young, Brewoo, Paykel, Weisgrau, Rakasz, Haller, Royals, Huang, Capuano, Stinchcomb, Partidos and Osorio. This is an open-access article distributed under the terms of the Creative Commons Attribution License (CC BY). The use, distribution or reproduction in other forums is permitted, provided the original author(s) orlicensor are credited and that the original publication in this journal is cited, in accordance with accepted academic practice. No use, distribution or reproduction is permitted which does not comply with these terms. 